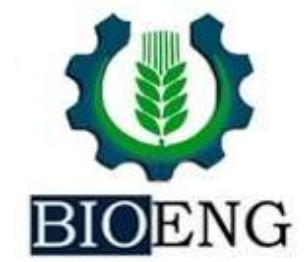

\title{
THERMAL PERFORMANCE OF AVIARY PROTOTYPES FITTED WITH OSB PANEL CEILING MADE OF BALSA WOOD WASTES
}

\author{
G. H. A. Barbirato* , W. E. Lopes Junior, D. C. G. Oliveira, \\ E. Y. Nagata, F. L. Caneppele, J. Fiorelli
}

USP - São Paulo University, Faculty of Animal Science and Food Engineering (FZEA), Pirassununga, SP, Brazil

Article history: Received 31 July 2019; Received in revised form 04 September 2019; Accepted 06 September 2019; Available online 30 September 2019.

\begin{abstract}
This study describes the potential of using an OSB panel ceiling, made of Balsa wood wastes agglomerated with a polyurethane resin based on castor oil, in prototypes of aviaries covered with fiber cement tiles. For the study, the internal temperature, relative humidity and the thermal comfort indexes, such as the environmental thermal index of productivity for broilers (IAPfc) and enthalpy, were measured and a Fuzzy logic classification system was used. The data were collected during the spring and summer, for 15 days. The results indicate that the presence of ceiling provided a reduction in the radiation transfer to the interior of the aviary prototypes, reflecting on the reduction of the ambient temperature and the thermal comfort indexes measured during spring and summer. Based on the Fuzzy classification system and on the data obtained, it can be concluded that there is a small difference between the aviaries with and without a ceiling.
\end{abstract}

Keywords: Ecological ceiling; Oriented Strand Board; Poultry facilities.

\section{DESEMPENHO TÉRMICO DE PROTÓTIPOS DE AVIÁRIOS PROVIDOS DE FORRO DE PAINEL OSB DE MADEIRA BALSA RESIDUAL}

\section{RESUMO}

Este estudo descreve o potencial do uso de um forro constituído de painel OSB, produzido a partir de resíduos de madeira de Balsa aglomerados com resina de poliuretano à base de óleo de mamona, em protótipos de aviários cobertos com telhas de fibrocimento. Para o estudo, foram analisados os índices de temperatura interna, umidade relativa e conforto térmico, como o índice térmico ambiental de produtividade para frangos de corte (IAPfc) e entalpia, e foi utilizado um sistema de classificação baseado em lógica fuzzy. Os dados foram coletados na primavera e no verão, durante o período de 15 dias. Os resultados obtidos indicaram que a presença do forro proporcionou uma redução na transferência de radiação para o interior dos protótipos avícolas, refletindo na redução da temperatura ambiente e nos índices de conforto térmico medidos durante a primavera e o verão. Com base no sistema de classificação fuzzy, pode-se concluir que há uma pequena diferença entre os aviários com e sem forro.

Palavras-chave: Forro particulado; Painel de partícula orientada; Instalações avícolas.

guilhermebarbirato@terra.com.br 


\section{INTRODUCTION}

In the last decades, the Brazilian broiler production has significantly increased, placing the country at the second position in the world scenario in 2016, with a total production of 12.9 million tons of broiler meat, only behind the United States with a production of 18.2 million tons. In third comes China, with a production of 12.3 million tons. Since 2010, Brazil has been the world leader in exporting chicken meat (ABPA, 2017).

According to OCDE/FAO projections (2017), meat production will increase by almost 40 million tons throughout the period from 2014 to 2026. This growth will mainly be driven by the production of broiler meat, which will increase from 117 thousand tons to 132 thousand tons, an increase of $13 \%$.

However, although the perspective for world poultry production is growing, broiler production still faces challenges that hinder a significant increase in productivity. Among these challenges, thermal stress is one of the factors that significantly influence the productive and reproductive performances of these animals. According to Navarini (2009), the environmental temperature is considered the physical factor of greater effect on the performance of the broilers since it influences the feed consumption, directly affecting the weight gain and the feed conversion.

Castro Júnior et al. (2017) evaluated the thermal comfort conditions in tow individuals calve shelter models covered with fiber cement tile without ceiling and using a ceiling made of low density particleboards from agro-industrial by-products $(40 \%$ sugarcane bagasse and $60 \%$ Pinus sp. shavings) bonded with polyurethane bi-component resin based on castor oil. The authors studied the ambience by dry bulb temperature (DBT), black globe temperature (BGT) and relative humidity $(\mathrm{RH})$ and they calculated the indices, such as Black Globe Temperature and Humidity Index (BGHI) and Radiant Thermal Load (RTL) and also thermographic images of the internal surface of the shelters. The results indicate that the presence of the ceiling did not contribute to a heat level reduction inside the shelters, which presented above the comfort conditions for the animals during the summer. Through observation, there was a reduction of the internal temperature of the surfaces of the shelter with a ceiling.

Thus, one of the alternatives for mitigating thermal stress in poultry facilities is the insertion of new insulation materials, to reduce the transfer of external radiation into the internal environment. In addition, to the different types of covers, the ceiling is another technique that can be applied in these installations. According to Tinôco (2001), the air layer between the cover and the ceiling forms a second physical barrier, which reduces the heat transfer to the inside of the installation.

Within this context, Carvalho (2013) investigated the effect of the ceiling on small-scale experimental prototypes in the region of Viçosa-MG, Brazil. The author evaluated the thermal efficiency of the polyethylene ceiling (the material used as a curtain in aviaries) and Foamular ${ }^{\circledR}$ ceiling (Extruded Polystyrene) based on the internal temperature. The authors found that the polyethylene and Foamular ceilings reduced the temperature by $2{ }^{\circ} \mathrm{C}$ and $4{ }^{\circ} \mathrm{C}$, respectively, in contrast with the experimental prototypes without a ceiling.

Barbirato et al. (2015) evaluated the thermal performance of calf shelter covered with fiber cement tiles and particleboard of wood shavings and sugarcane bagasse combined with insulation materials. The authors found that temperature and humidity indexes (THI) and the internal environment temperature of the facilities with ceiling combined with isopor ${ }^{\circledR}$ slabs and polyurethane castor oil boards were lower, $2.69 \%$ and $1.88 \%$, respectively, than those measured in the shelters without a ceiling.

Cravo et al. (2015) investigated the lining such as an alternative to smoothen the flow of heat to the interior of the 
poultry housing. The authors studied the thermal properties and durability of the effect on the mechanical properties of a composite based agricultural waste for use as lining in poultry houses. Peanut shell and coconut fiber were used (50:50) and $15 \%$ bi-component polyurethane resin based on castor oil. The thermal results reported that the composite has potential for application as thermal insulation, while the evaluation of the durability revealed the need to incorporate a coating to ensure consistency of mechanical properties of the composite.

Cravo et al. (2017) evaluated the thermal performance of cement bag particleboard coated with long-life packaging applied as a ceiling in a prototype aviary. The data were collected for 15 days in the spring season of 2014 and summer, fall and winter of 2015. The internal temperature in the prototype, enthalpy and the environmental thermal index of productivity for broilers (IAPfc) were determined. For the internal temperature, the author verified average values of 28.24 and $29.38^{\circ} \mathrm{C}$, in the spring, and 29.45 and $31.05^{\circ} \mathrm{C}$, in the summer, for the environments with and without ceiling, respectively. Regarding the thermal comfort indexes (enthalpy and IAPfc), the author found in the interior of the prototypes enthalpy values of 65.50 and $67.06 \mathrm{~kJ} / \mathrm{kg}$ of dry air, during the spring, and values of 69.83 and $73.90 \mathrm{~kJ} / \mathrm{kg}$ of dry air, over the summer, for both environments with and without ceiling, respectively. For the IAPfc, the authors obtained as a result values equal to 29.21 and 30.74, in the spring, and 31.69 and 34.61 , in the summer, for the environments with and without ceiling, respectively. Therefore, all the analyses made by the author showed that there was a statistical difference between the prototype provided with the ceiling in comparison to the prototype without a ceiling.

Schiassi et al. (2015), with the objective to analyzing the effect of age and air temperature in broiler performance, carried out an experiment with reared animals from 1 to 21 days of life in air- conditioned wind tunnels and the observed results were used in the development and test of a fuzzy mathematical model able to quantify this relation.

Cravo et al. (2014) studied the thermal properties of an ecological liner low density particle-based on agribusiness residues (peanut hulls and coconut fiber) agglutinated with bi-component polyurethane resin based on castor oil and evaluate its performance when applied as lining in poultry houses. The results show that the material has the potential to be used as lining in poultry broiler.

Lopes Júnior et al. (2019) analyzed thermal indices in prototypes of aviaries built in a reduced and distorted scale, with and without commercial mineral fiber lining from Ecomin Filigran model. The productivity indices for broilers (Enthalpy and the environmental productivity index for broiler chickens - EPIbc) were calculated to evaluate the efficiency of the linings. The results indicated that the prototype with lining presented lower values than the prototypes without lining in the order of $6.03 \%$ for the maximum average temperature, $7.38 \%$ for Enthalpy and $11.26 \%$ for the EPIbc.

Lopes et al. (2011), with the purpose of evaluating and presenting the application of fuzzy logic in the analysis of the variables that affect the ambience of broilers, showed that this tool is of great importance, it contributes to the decisionmaking and allows a better thermal environment control for broiler production.

Among the challenges faced by poultry production, the importance of the quality of the environment it is fundamental, especially in tropical countries. One of the methodologies currently used is the Fuzzy logic, i.e., in decision-making or common sense, based on human logic translated into mathematical concepts for the solution of a variety of problems.

According to Simões \& Shaw (2007) fuzzy logic provides a method of transforming vague, inaccurate, and qualitative verbal expressions common in human dialogic into numerical values. 
The same authors explain that the advance made possible by fuzzy treatment has a great practical value, in which it becomes possible to include the experience of human specialists in computerized controllers, favoring decision making modalities in complex problems.

All these characteristics, coupled with the use of ceiling in rural facilities, which proves to be an efficient technology to provide a comfortable environment, especially considering the climatic changes

\section{MATERIAL AND METHODS}

\section{Ceiling production}

For the production of the ceiling, Balsa wood (Ochroma Pyramidale) wastes were used. Initially, these residues were chopped on a band saw to standardize the size of the wood pieces, and then inserted in a knife mill to produce the wood chips. The particles were then transferred to an oven at $60{ }^{\circ} \mathrm{C}$ for 48 hours in order to homogenize the moisture content of the chips. Subsequently, the Balsa wood waste chips were separated in a 25:50:25 layer ratio. Afterward, the castor oil polyurethane resin was added by spaying, in a ratio based on the dry weight of the particles $(15 \%)$.

After adding the resin, the material was transferred into a planetary mixer for 3 minutes to ensure homogeneous distribution of the resin over the particles. The material was then placed in a forming that will occur in the world in the upcoming decades.

Therefore, the aim of this study was to evaluate the thermal performance of OSB particleboard made of Balsa wood wastes agglomerated with polyurethane resin-based in castor oil, applied as a ceiling in aviary prototypes covered with fiber cement tiles, coupled with a Fuzzy classification system to evaluate the efficiency of the panels.

pad and inserted in a thermohydraulic press, at $100{ }^{\circ} \mathrm{C}$ and a pressure of 50 $\mathrm{kg} / \mathrm{m}^{2}$, for 10 minutes. Resulting in manufactured particleboard with dimensions of $40 \times 40$, the thickness of 1 $\mathrm{cm}$ and an average density of $400 \mathrm{~kg} / \mathrm{m}^{3}$.

\section{Thermal analysis of the prototypes}

The OSB panels of Balsa wood wastes (Figure 1a) were installed in individual aviary prototypes, located in the experimental field of the Faculty of Animal Science and Food Engineering/USP, Pirassununga - SP, which presents the subtropical Cwa climate type of Köppen, with dry winter and hot and rainy summer. Small-scale and distorted experimental aviary prototypes (Table 1) were used to evaluate the thermal efficiency of building elements in poultry production.

Table 1: Experimental prototype dimensions.

\begin{tabular}{c|c|c|c}
\hline \multirow{2}{*}{} & \multicolumn{3}{|c}{ Dimensions } \\
\cline { 2 - 4 } & $\begin{array}{c}\text { Actual } \\
(\mathrm{m})\end{array}$ & $1: 10$ & $1: 2$ \\
\hline Width & 15.00 & 1.40 & \\
\hline Length & 30.00 & 3.00 & \\
\hline Eaves & 2.00 & 0.20 & \\
\hline Ceiling height & 3.00 & & 1.50 \\
\hline Wall height & 0.80 & & 0.40 \\
\hline Wall thickness & 0.20 & & 0.10 \\
\hline
\end{tabular}

Source: Cravo et al. (2017).

These facilities were provided with fiber cement cover, blue-colored plastic curtains, for side closing, and white painted walls. The flooring was made by 
OSB particleboard. Within each prototype, data loggers (HOBO) were placed at $30 \mathrm{~cm}$ above the ground (center of gravity of the bird) in order to gauge environmental temperature, dew point temperature and relative humidity data (Figure $1 \mathrm{~b}$ and $\mathrm{c}$ ). Throughout the experiment, the plastic curtains and the attic remained closed.
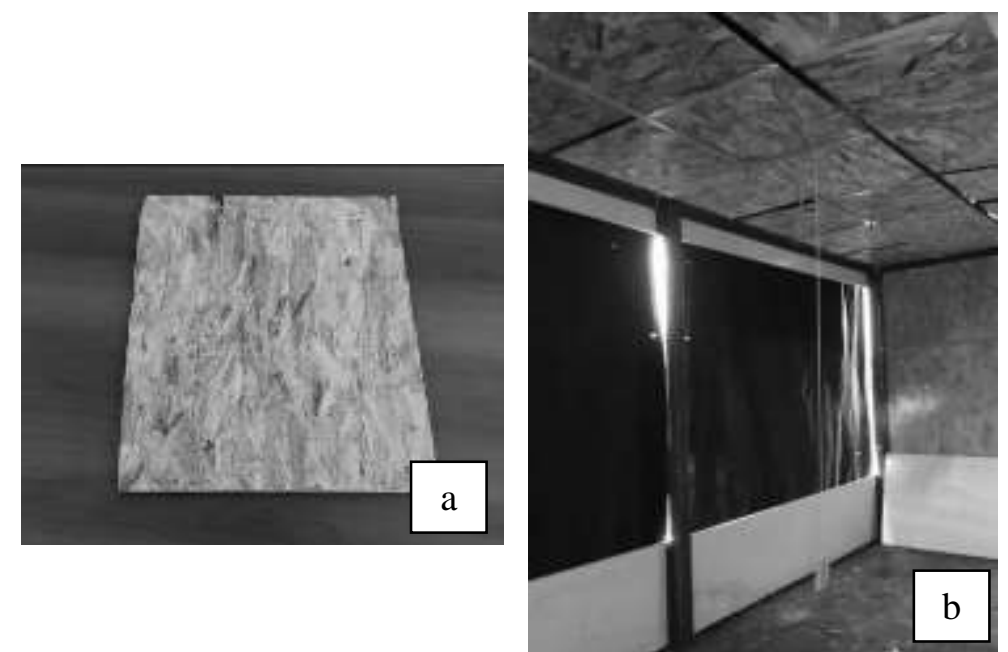

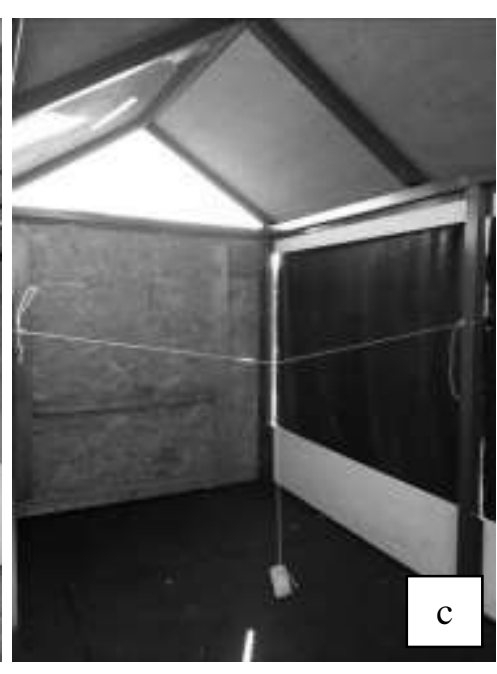

Figure 1: (a) OSB panel; (b) Prototype with ceiling; (c) Prototype without ceiling.

These thermal variables were quantified throughout the day and night, for 15 days during the spring (period with milder temperatures) of 2017 and summer (period with high temperatures) of 2018, considered to be the transition period between the seasons. The days of data collection were critical, corresponding to days presenting no rain or clouds.

With the environmental temperature, relative humidity, wind speed, and barometric pressure data from the meteorological station, the environmental thermal index of productivity for broilers (IAPfc) and the enthalpy were determined by applying the equations developed by Medeiros et al. (2005) e Rodrigues et al. (2011), respectively.
The data from the internal environment of the prototypes (with and without ceiling) were collected at 08:00 a.m., 10:00 a.m., 12:00 am, 2:00 p.m., 4:00 p.m. and 6:00 p.m. for the day and 8:00 p.m., 10:00 p.m., 12:00 a.m., 02:00 a.m., 04:00 a.m. and 06:00 a.m. for the night. The qualitative data (factor - conditioning) were analyzed through the Tukey multiple comparison test, at $\mathrm{P}<0.05$. SAS was used for data processing.

\section{Fuzzy logic system}

The Fuzzy logic based software was developed on the demo version of the Fuzzy Tech Software and the input and output variables were analyzed through the data obtained in the experiment, generating the system shown in Figure 2.

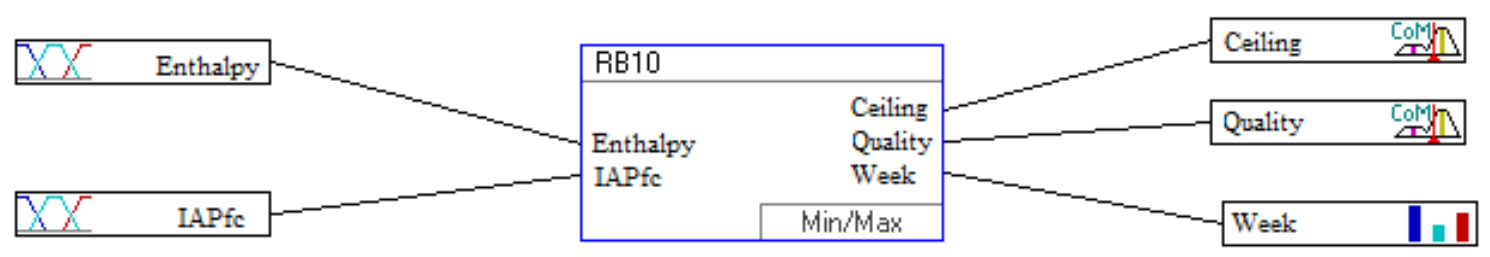

Figure 2: Fuzzy classification system. 
The Fuzzy system model has 2 input variables (Enthalpy and IAPfc), in which the values obtained by the measurements of the environment in the aviary are inserted. From this data, an analysis is made and, through Fuzzy rules, it is possible to determine three output variables (Ceiling, Quality, Week). The variable "Ceiling" means the presence or not of OSB panel in the aviary, the variable "Quality" describes how good or bad the

\section{RESULTS AND DISCUSSION}

\section{Thermal indexes}

The summary of the mean values for internal temperature, relative humidity, enthalpy, and IAPfc for the day and night ceiling is in a given situation, and the variable "Week" describes which of the 6 weeks, from the tables presented by Barbosa Filho et al. (2007), is adequate to the proposed environment. Based on the system observations, the fuzzy system variables were chosen. The inference method used was that of Mandani. A total of 42 if-then rules were used, correlating input variables with output variables.

periods during the spring of 2017 and summer of 2018 are presented in Tables 2 and 3.

Table 2: Mean values of thermal variables for the spring of 2017.

\begin{tabular}{|c|c|c|c|c|c|c|c|c|c|}
\hline \multirow{3}{*}{ Period } & \multirow{3}{*}{ Hour } & \multicolumn{8}{|c|}{ Spring } \\
\hline & & \multicolumn{4}{|c|}{ With ceiling } & \multicolumn{4}{|c|}{ Without ceiling } \\
\hline & & $\begin{array}{l}\text { Temp. } \\
\left({ }^{\circ} \mathrm{C}\right)\end{array}$ & $\begin{array}{l}\text { RH } \\
(\%)\end{array}$ & $\begin{array}{l}\text { Enthalpy } \\
(\mathrm{kJ} / \mathrm{kg})\end{array}$ & $\begin{array}{c}\text { IAPfc } \\
(\%)\end{array}$ & $\begin{array}{l}\text { Temp. } \\
\left({ }^{\circ} \mathrm{C}\right)\end{array}$ & $\begin{array}{l}\mathrm{RH} \\
(\%)\end{array}$ & $\begin{array}{c}\text { Enthalpy } \\
(\mathrm{kJ} / \mathrm{kg})\end{array}$ & $\begin{array}{c}\text { IAPfc } \\
(\%)\end{array}$ \\
\hline \multirow{6}{*}{ Day } & 8 & $14.3^{\mathrm{a}}$ & $82.7^{\mathrm{a}}$ & $35.9^{\mathrm{a}}$ & $17.0^{\mathrm{a}}$ & $14.6^{\mathrm{a}}$ & $85.3^{b}$ & $37.2^{\mathrm{a}}$ & $17.2^{\mathrm{a}}$ \\
\hline & 10 & $25.9^{\mathrm{a}}$ & $52.2^{\mathrm{a}}$ & $54.1^{\mathrm{a}}$ & $24.2^{\mathrm{a}}$ & $27.1^{b}$ & $50.4^{\mathrm{a}}$ & $56.3^{\mathrm{a}}$ & $25.5^{\mathrm{a}}$ \\
\hline & 12 & $31.1^{\mathrm{a}}$ & $38.8^{\mathrm{a}}$ & $59.5^{\mathrm{a}}$ & $29.5^{\mathrm{a}}$ & $32.6^{b}$ & $36.7^{b}$ & $61.8^{\mathrm{a}}$ & $31.5^{b}$ \\
\hline & 14 & $32.4^{\mathrm{a}}$ & $34.6^{\mathrm{a}}$ & $59.5^{\mathrm{a}}$ & $31.3^{\mathrm{a}}$ & $33.6^{\mathrm{a}}$ & $33.0^{\mathrm{a}}$ & $61.2^{\mathrm{a}}$ & $33.0^{\mathrm{b}}$ \\
\hline & 16 & $31.0^{\mathrm{a}}$ & $35.0^{\mathrm{a}}$ & $56.3^{\mathrm{a}}$ & $29.4^{\mathrm{a}}$ & $31.3^{\mathrm{a}}$ & $34.2^{\mathrm{a}}$ & $56.5^{\mathrm{a}}$ & $29.7^{\mathrm{a}}$ \\
\hline & 18 & $21.4^{\mathrm{a}}$ & $50.2^{\mathrm{a}}$ & $42.0^{\mathrm{a}}$ & $19.8^{\mathrm{a}}$ & $20.6^{\mathrm{a}}$ & $50.9^{\mathrm{a}}$ & $40.5^{\mathrm{a}}$ & $19.3^{\mathrm{a}}$ \\
\hline \multirow{6}{*}{ Night } & 20 & $15.9^{\mathrm{a}}$ & $65.3^{\mathrm{a}}$ & $34.8^{\mathrm{a}}$ & $17.3^{\mathrm{a}}$ & $15.2^{\mathrm{a}}$ & $68.1^{\mathrm{a}}$ & $34.0^{\mathrm{a}}$ & $17.2^{\mathrm{a}}$ \\
\hline & 22 & $13.5^{\mathrm{a}}$ & $73.2^{\mathrm{a}}$ & $31.5^{\mathrm{a}}$ & $16.8^{\mathrm{a}}$ & $12.9^{\mathrm{a}}$ & $76.3^{b}$ & $31.0^{\mathrm{a}}$ & $16.7^{b}$ \\
\hline & 24 & $12.1^{\mathrm{a}}$ & $78.1^{\mathrm{a}}$ & $29.8^{\mathrm{a}}$ & $16.6^{\mathrm{a}}$ & $11.6^{\mathrm{a}}$ & $81.1^{\mathrm{b}}$ & $29.2^{\mathrm{a}}$ & $16.6^{\mathrm{a}}$ \\
\hline & 2 & $10.5^{\mathrm{a}}$ & $82.5^{\mathrm{a}}$ & $27.1^{\mathrm{a}}$ & $16.5^{\mathrm{a}}$ & $9.9^{\mathrm{a}}$ & $85.5^{\mathrm{b}}$ & $26.5^{\mathrm{a}}$ & $16.5^{\mathrm{a}}$ \\
\hline & 4 & $9.5^{\mathrm{a}}$ & $85.5^{\mathrm{a}}$ & $25.7^{\mathrm{a}}$ & $16.6^{\mathrm{a}}$ & $9.0^{\mathrm{a}}$ & $88.4^{\mathrm{b}}$ & $25.2^{\mathrm{a}}$ & $16.6^{\mathrm{a}}$ \\
\hline & 6 & $8.8^{\mathrm{a}}$ & $87.0^{\mathrm{a}}$ & $24.6^{\mathrm{a}}$ & $16.7^{\mathrm{a}}$ & $8.3^{\mathrm{a}}$ & $90.1^{b}$ & $24.1^{\mathrm{a}}$ & $16.7^{\mathrm{a}}$ \\
\hline
\end{tabular}

Means followed by different lowercase letters in the row differ significantly at $5 \%$ by the Tukey Test

Where: Temp = Relative air temperature; $\mathrm{RH}=$ Relative humidity; IAPfc $=$ Thermal index of productivity for broilers.

Table 3: Mean values of the thermal variables for the summer of 2018.

\begin{tabular}{|c|c|c|c|c|c|c|c|c|c|}
\hline \multirow{3}{*}{ Period } & \multirow{3}{*}{ Hour } & \multicolumn{8}{|c|}{ Summer } \\
\hline & & \multicolumn{4}{|c|}{ With ceiling } & \multicolumn{4}{|c|}{ Without ceiling } \\
\hline & & $\begin{array}{l}\text { Temp. } \\
\left({ }^{\circ} \mathrm{C}\right)\end{array}$ & $\begin{array}{l}\text { RH } \\
(\%)\end{array}$ & $\begin{array}{c}\text { Enthalpy } \\
(\mathrm{kJ} / \mathrm{kg})\end{array}$ & $\begin{array}{c}\text { IAPfc } \\
(\%)\end{array}$ & $\begin{array}{l}\text { Temp. } \\
\left({ }^{\circ} \mathrm{C}\right)\end{array}$ & $\begin{array}{l}\mathrm{RH} \\
(\%)\end{array}$ & $\begin{array}{c}\text { Enthalpy } \\
(\mathrm{kJ} / \mathrm{kg})\end{array}$ & $\begin{array}{c}\text { IAPfc } \\
(\%)\end{array}$ \\
\hline \multirow{4}{*}{ Day } & 8 & $22.7^{\mathrm{a}}$ & $82.6^{\mathrm{a}}$ & $65.3^{\mathrm{a}}$ & $23.6^{\mathrm{a}}$ & $22.8^{\mathrm{a}}$ & $89.8^{\mathrm{b}}$ & $69.5^{\mathrm{a}}$ & $24.7^{b}$ \\
\hline & 10 & $29.4^{\mathrm{a}}$ & $68.8^{\mathrm{a}}$ & $82.9^{a}$ & $31.6^{\mathrm{a}}$ & $33.0^{b}$ & $61.5^{\mathrm{a}}$ & $90.7^{\mathrm{a}}$ & $37.4^{\mathrm{b}}$ \\
\hline & 12 & $34.5^{\mathrm{a}}$ & $54.9^{\mathrm{a}}$ & $91.8^{\mathrm{a}}$ & $38.8^{\mathrm{a}}$ & $36.5^{b}$ & $51.6^{\mathrm{a}}$ & $96.5^{\mathrm{a}}$ & $42.5^{\mathrm{b}}$ \\
\hline & 14 & $37.7^{\mathrm{a}}$ & $46.8^{\mathrm{a}}$ & $95.9^{\mathrm{a}}$ & $43.7^{\mathrm{a}}$ & $39.7^{b}$ & $44.2^{\mathrm{a}}$ & $101.0^{\mathrm{a}}$ & $48.1^{\mathrm{b}}$ \\
\hline
\end{tabular}




\begin{tabular}{cccccccccc}
\hline & 16 & $36.6^{\mathrm{a}}$ & $46.6^{\mathrm{a}}$ & $91.3^{\mathrm{a}}$ & $42.2^{\mathrm{a}}$ & $38.0^{\mathrm{a}}$ & $45.7^{\mathrm{a}}$ & $95.4^{\mathrm{a}}$ & $45.7^{\mathrm{a}}$ \\
\cline { 2 - 9 } Nigth & 18 & $30.9^{\mathrm{a}}$ & $58.4^{\mathrm{a}}$ & $79.7^{\mathrm{a}}$ & $33.5^{\mathrm{a}}$ & $31.1^{\mathrm{a}}$ & $61.3^{\mathrm{a}}$ & $81.8^{\mathrm{a}}$ & $34.4^{\mathrm{a}}$ \\
\hline & 20 & $25.0^{\mathrm{a}}$ & $72.3^{\mathrm{a}}$ & $67.9^{\mathrm{a}}$ & $25.1^{\mathrm{a}}$ & $24.6^{\mathrm{a}}$ & $76.9^{\mathrm{a}}$ & $68.8^{\mathrm{a}}$ & $25.2^{\mathrm{a}}$ \\
\cline { 2 - 9 } & 22 & $22.9^{\mathrm{a}}$ & $79.1^{\mathrm{a}}$ & $62.6^{\mathrm{a}}$ & $23.4^{\mathrm{a}}$ & $22.6^{\mathrm{a}}$ & $85.4^{\mathrm{b}}$ & $64.6^{\mathrm{a}}$ & $23.8^{\mathrm{a}}$ \\
\cline { 2 - 9 } & $22.4^{\mathrm{a}}$ & $81.1^{\mathrm{a}}$ & $61.8^{\mathrm{a}}$ & $22.7^{\mathrm{a}}$ & $22.1^{\mathrm{a}}$ & $87.8^{\mathrm{b}}$ & $64.0^{\mathrm{a}}$ & $23.1^{\mathrm{a}}$ \\
\cline { 2 - 9 } & $21.8^{\mathrm{a}}$ & $81.8^{\mathrm{a}}$ & $60.3^{\mathrm{a}}$ & $22.2^{\mathrm{a}}$ & $21.6^{\mathrm{a}}$ & $89.4^{\mathrm{b}}$ & $63.0^{\mathrm{a}}$ & $22.8^{\mathrm{a}}$ \\
\cline { 2 - 8 } & $21.3^{\mathrm{a}}$ & $82.8^{\mathrm{a}}$ & $59.1^{\mathrm{a}}$ & $21.9^{\mathrm{a}}$ & $21.1^{\mathrm{a}}$ & $91.5^{\mathrm{b}}$ & $62.2^{\mathrm{a}}$ & $22.6^{\mathrm{b}}$ \\
\hline & 4 & $20.7^{\mathrm{a}}$ & $83.3^{\mathrm{a}}$ & $57.1^{\mathrm{a}}$ & $21.2^{\mathrm{a}}$ & $20.4^{\mathrm{a}}$ & $92.7^{\mathrm{b}}$ & $60.4^{\mathrm{a}}$ & $22.0^{\mathrm{b}}$ \\
\hline
\end{tabular}

Means followed by different lowercase letters in the row differ significantly at $5 \%$ by the Tukey Test

Where: Temp = Relative air temperature; $\mathrm{RH}=$ Relative humidity; IAPfc $=$ Thermal index of productivity for broilers.

In Figure 3 shows the dispersion points of the mean values for internal temperature for the day and night periods

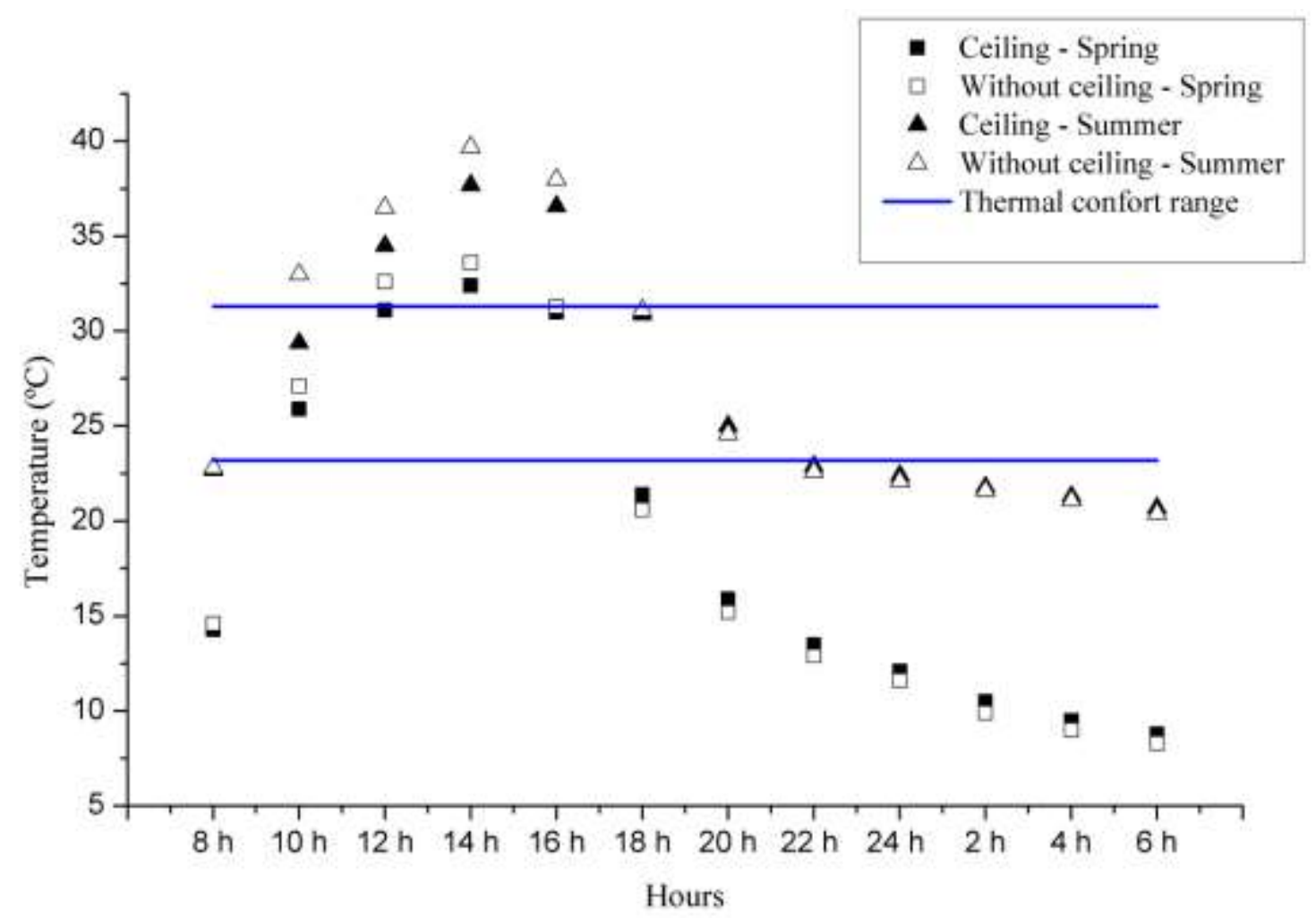

Figure 3: Mean values of the internal ambient temperature of the prototypes.

According to Cassuce (2011), the estimated thermal comfort zone for broilers in the first six weeks of life are: $31.3^{\circ} \mathrm{C}$ in the first week, between 26.3 and $27.1^{\circ} \mathrm{C}$ in the second week, between 22.5 and $23.2^{\circ} \mathrm{C}$ in the third week and $23^{\circ} \mathrm{C}$ between the fourth and sixth week. Figure 3 demonstrates that the temperatures of the prototype with ceiling was lower than that for the prototype without ceiling, for the hours of higher radiation incidence during during the spring of 2017 and summer of 2018 are presented. 
When analyzing the prototypes during the night (Figure 3), both showed contrary characteristics when compared to daytime. The prototypes without ceiling, with high temperatures during the day, had a significant heat loss during the night. While the prototypes with a ceiling, due to their architectural features, have preserved the heat in, proving to be a good option for more rigorous climates.

The concept of relative humidity is the relation between the amount of water vapor present in the air and its maximum possible amount, under a certain temperature. Therefore, the relative humidity is inversely proportional to the air temperature, since it controls the maximum humidity in a volume of air (MENDONÇA and DANNI-OLIVEIRA, 2011).

According to Tinôco (2001), relative air humidity between 50 to $70 \%$ is comfortable for adult broilers when the air temperature is between 15 to $18{ }^{\circ} \mathrm{C}$ and 22 to $25{ }^{\circ} \mathrm{C}$. However, it should be noted that the values of the ambient temperature in the prototypes were higher than those pointed by the author, as shown in Tables 2 and 3.

Evaporative cooling is defined as a heat loss mechanism that birds use in hightemperature environments. This is because broilers have the ability to raise the respiratory rate by up to 10 times. However, for this mechanism to work properly, the low relative humidity for the environment is necessary, otherwise, the birds will accumulate thermal energy and consequently will experience thermal stress (FURLAN and MACARI, 2002).

In Figure 4 shows the dispersion points of the mean values for relative humidity for the day and night periods during the spring of 2017 and summer of 2018 are presented.

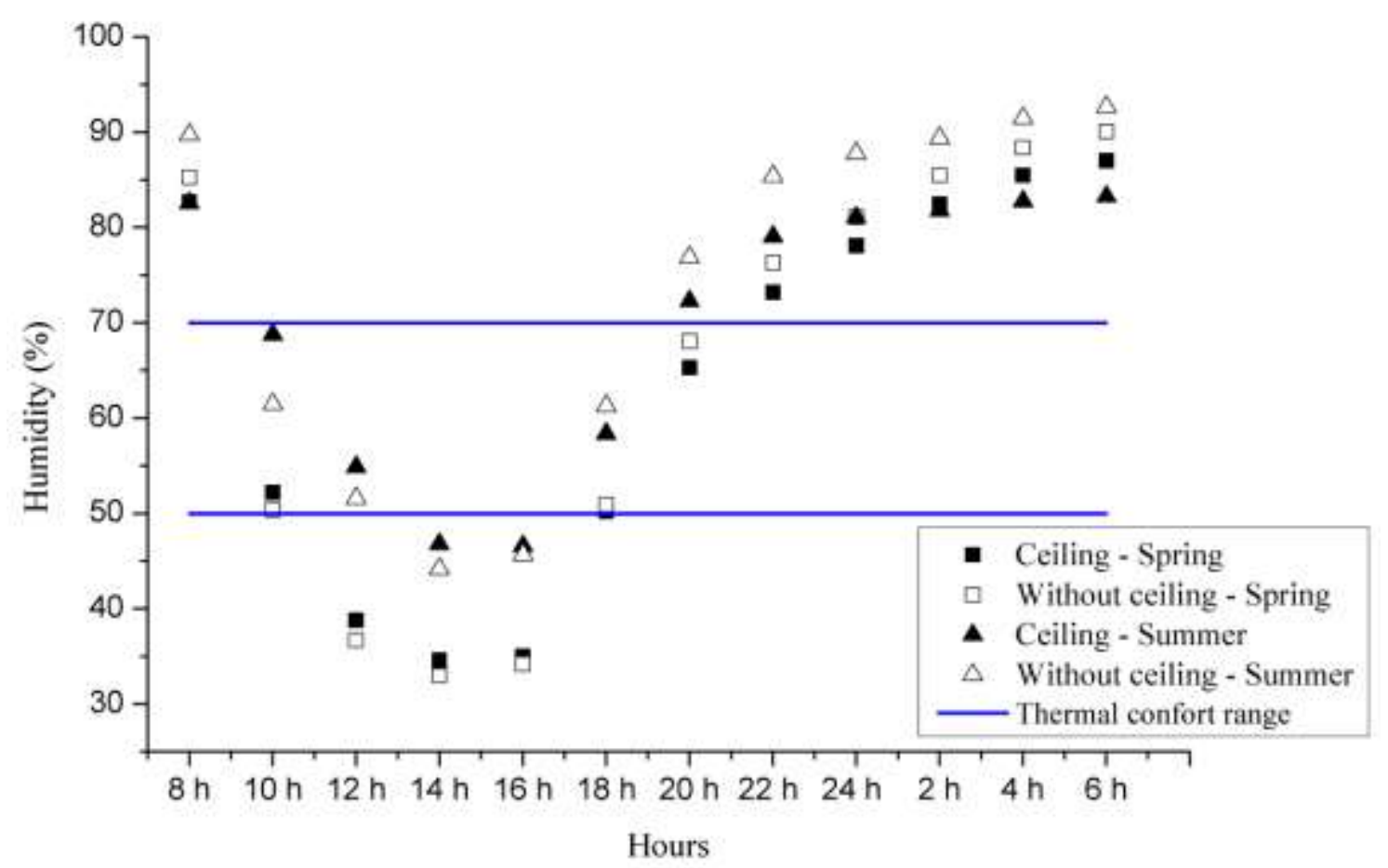

Figure 4: Mean values of the internal relative humidity of the prototypes.

Moreover, Figure 4 shows that the highest values of relative humidity inside the prototypes occurred at 08:00 a.m., for spring and summer seasons. These data show that, during this time of the day, the broilers have greater difficulty in losing heat by the evaporative mechanism. However, in the hottest hours of the day 
(from 10:00 a.m. to 16:00 p.m.), only at 10:00 am during spring and summer, and at 12:00 noon during summer, presented compatible values within 50 to $70 \%$ as proposed by Tinôco (2001). For the other moments during the day, only at 18:00 p.m. the values of relative humidity established by the author were met. Therefore, facilities with and without ceiling at critical times require the use of evaporative systems. During the night, any measurement after 10:00 pm did not meet the 50 to $70 \%$ relative humidity proposed by Tinôco (2001).

The enthalpy can be described as the amount of energy in a water vapor mixture. The variation in the air temperature, relative humidity, and barometric pressure, in a given environment, modifies the amount of energy in the air and influence in the thermal exchanges between the animal and the environment (LOURENÇONI, 2013).

This index is related to the environmental temperature and relative humidity results. During the spring, these two variables were differently $(\mathrm{P}<0.05)$. As the prototype with the ceiling, in the daytime period, presented lower environmental temperature compared to the prototype without ceiling, the enthalpy in this facility was lower. However, as this situation is reversed at night, the enthalpy of the prototype with the ceiling was greater than the value for the prototype without a ceiling. Figure 5 shows the data related to the calculation of the enthalpy for the prototypes with and without ceiling, where this phenomenon can be observed.

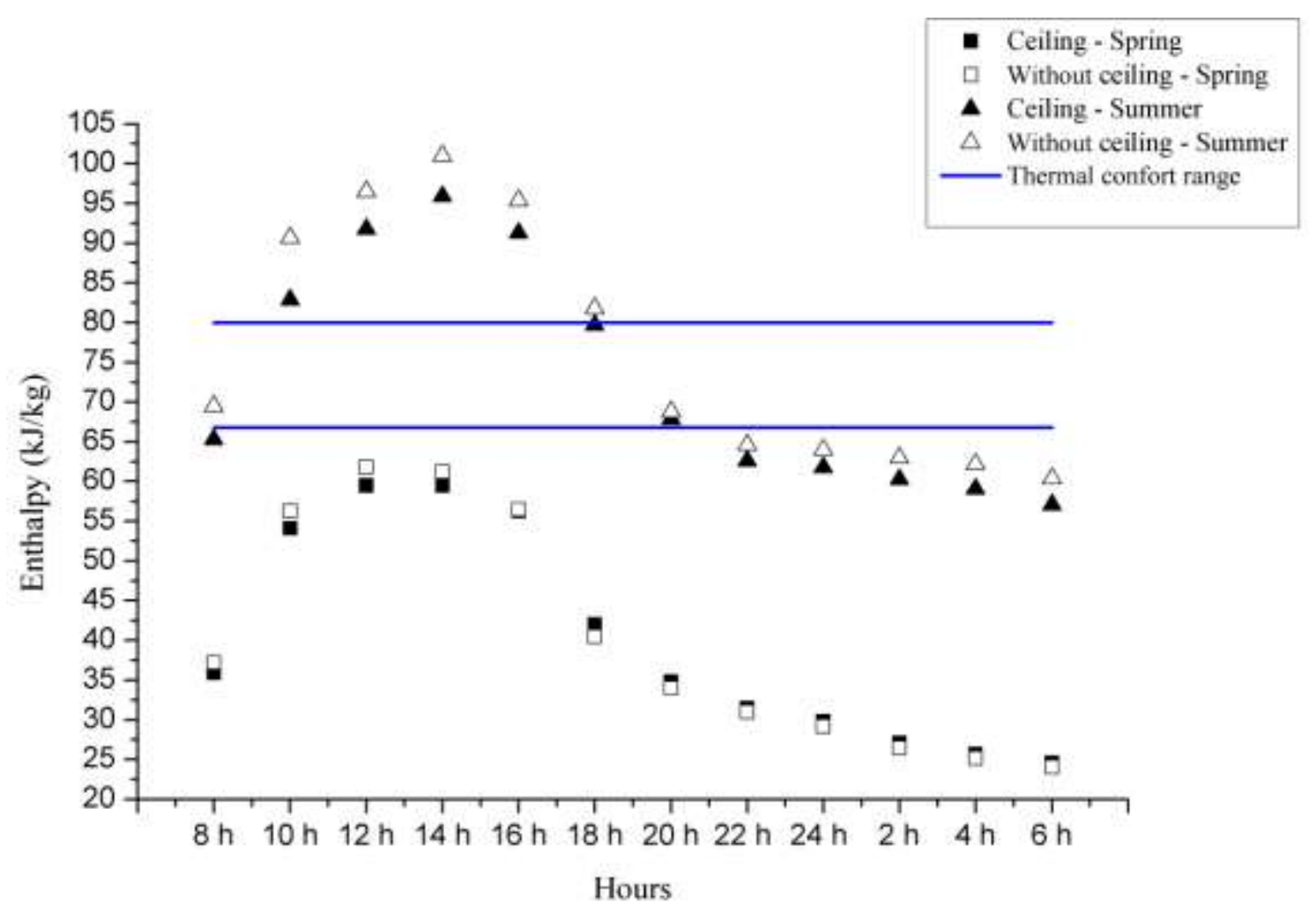

Figure 5: Mean enthalpy values of the prototypes.

According to Barbosa Filho et al. (2007) the thermal comfort enthalpy for broilers corresponds to 80 to $86.6 \mathrm{~kJ} / \mathrm{kg}$ of dry air in the first week of life, 73 to 79.9 for the second week, 66.8 to 73.9 for third week, 63 to 68.2 during the fourth week, 56.3 to 64.6 during the fifth week and, finally, 54.7 to 62.9 for the sixth week of life.

It can noted, from Figure 5, that during the most critical period of the day (from 10:00 a.m. to $16: 00$ p.m.), only the prototype fitted with ceiling, at 10:00 a.m., presented thermal comfort corresponding 
to the first week of life, while at the other times, the environment exhibited thermal discomfort caused by heat. It is also observed that the enthalpy showed more clearly the effect of using the ceiling in the installation since the ambient temperature and the relative humidity of the air influence its results, which is justified in the morning period in Table 2.

During the night, both prototypes presented thermal discomfort in the first two weeks. Although the prototype with ceiling presented lower thermal discomfort compared to the environment without ceiling, it is noteworthy that this decrease in thermal discomfort, due to colder temperatures, tends to reduce the use of heaters at night or use of cooling equipment during the day.
The IAPfc is defined by a statistical index of thermal comfort in order to evaluate the thermal environment for broilers. The characterization of this index relates air temperature, relative humidity, and wind speed.

Similarly to the enthalpy, the ambient temperature and relative humidity were the variables that had the greatest influence on the performance of the IAPFc in the prototypes, since the statistical difference was found for these thermal variables. Thus, it is possible to visualize in Figure 6 that the prototype with ceiling presented a significant difference for the IAPfc, in both the spring of 2017 and the summer of 2018.

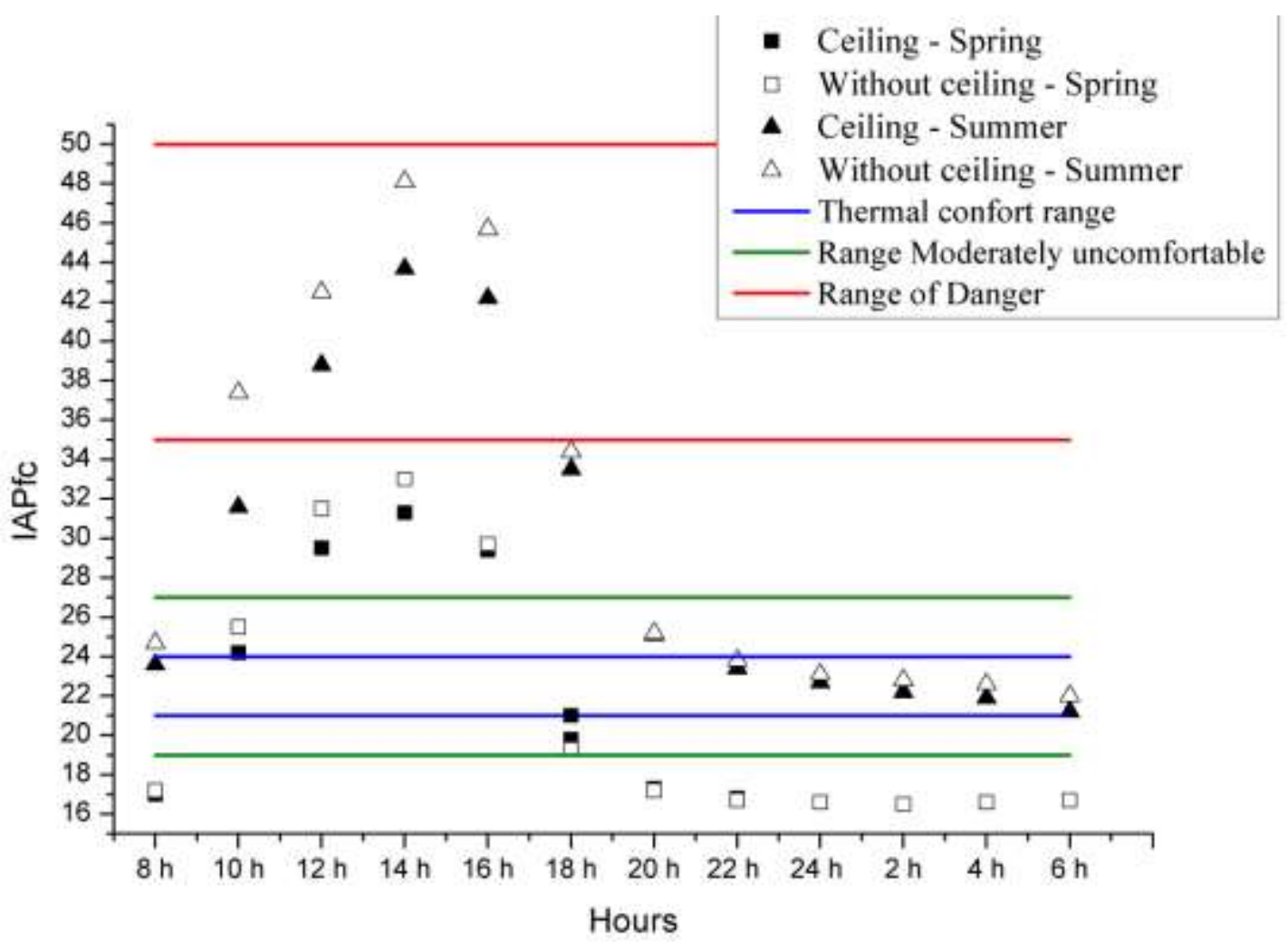

Figure 6: Mean values of IAPfc of the prototypes.

Medeiros et al. (2005), classified the IAPfc values as thermal comfortable environment if in the range of 21 to 24 ; between the ranges of 19 to 20 and 25 to 27 as moderately uncomfortable; between 28 to 30 and below 19 as uncomfortable; between 31 to 34 as extremely uncomfortable and dangerous when the value is equal to or greater than 35 .

Therefore, it is possible to observe in Figure 8, in general, that the thermal environment of the prototypes with ceiling presented lower values than the prototypes without ceiling during the hottest hours of the day. However, in order to classify the 
measureament times based on the IAPfc values, it is observed that at 08:00 a.m., the prototype with ceiling was classified as comfortable, 10:00 a.m. and 18:00 p.m. were the periods classified as extremely uncomfortable, while at all other times, the environment was dangerous for birds in both the prototypes, with and without ceiling.

In the case of the night period, Figure 6 shows that at all measurement times for the summer season of 2018, the prototypes with ceiling presented lower values when compared with the prototypes without a ceiling. Noted that at 20:00 p.m., it was moderately uncomfortable for both prototypes.

\section{Fuzzy logic analysis}

The objective of the fuzzy system was to simulate the data input of the enthalpy and IAPfc variations and classify it in an efficient way, within the indexes of quality, ideal week and the type of ceiling.

Through the analyses of the data collected in the experiment, it can be affirmed that the prototypes with the ceiling and without ceiling have a small difference in the collected data and that the fuzzy classification system was able to precisely distinguish the prototypes, even with minimal differences between them, as shown in Table 3.

Table 3: Simulations with the fuzzy classification system.

\begin{tabular}{c|c|c|c|c|c}
\hline Type of Aviary & IAPFc* & Enthalpy* & Quality & Ideal Week & Ceiling \\
\hline $\begin{array}{c}\text { With Ceiling (Day- } \\
\text { Spring) }\end{array}$ & 35.6 & 84.5 & Terrible & First Week & + \\
\hline $\begin{array}{c}\text { Without Balsa ceiling } \\
\text { (Day-Spring) }\end{array}$ & 38.8 & 89.2 & Terrible & First Week & + \\
\hline $\begin{array}{c}\text { With Ceiling (Nigth- } \\
\text { Spring) }\end{array}$ & 16.8 & 28.9 & Moderately bad & Sixth Week & $=$ \\
\hline $\begin{array}{c}\text { Without Balsa ceiling } \\
\text { (Nigth-Spring) }\end{array}$ & 16.7 & 28.33 & Moderately bad & Sixth Week & $=$ \\
\hline $\begin{array}{c}\text { With Ceiling (Day- } \\
\text { Summer) }\end{array}$ & 35.6 & 84.5 & Terrible & First Week & + \\
\hline $\begin{array}{c}\text { Without Balsa ceiling } \\
\text { (Day-Summer) }\end{array}$ & 38.8 & 89.2 & Terrible & First Week & + \\
\hline $\begin{array}{c}\text { With Ceiling (Night- } \\
\text { Summer) }\end{array}$ & 22.8 & 61.6 & Great & Fifth Week & $=$ \\
\hline $\begin{array}{c}\text { Without Balsa ceiling } \\
\text { (Night-Summer) }\end{array}$ & 23.3 & 63.8 & Great & Fifth Week & - \\
\hline
\end{tabular}

* mean values.

$(+)$ - With OSB panel

(-) - Without OSB panel

(=) - Undefined (With / Without OSB Panel)

\section{CONCLUSIONS}

The application of the OSB panel of Balsa wood wastes as a ceiling provided a reduction in the thermal energy transfer into the interior of the evaluated aviary prototypes. As a consequence, there is a decrease in the environmental temperature and the thermal comfort indexes measured during spring and summer, which are the seasons considered more challenging for broilers. In relation to the Fuzzy system, even though a reduction of the ambient temperature occurs, to create a better classification system, more experimental data are necessary since the available data characterize a small difference between the 
aviary with the OSB panel of Balsa wood

\section{ACKNOWLEDGMENTS}

The authors would like to thank FAPESP (proc. 2017/18076-4) for their research support.

\section{REFERENCES}

ASSOCIAÇÃO BRASILEIRA DE PROTEÍNA ANIMAL - ABPA. Relatório anual da avicultura, 2017. http://abpabr.com.br/storage/files/3678c_fi nal_abpa_relatorio_anual_2016_portugues _web_reduzido.pdf. 11 Jul. 2017.

BARBIRATO, G. H. A.; FIORELLI, J. ; LINO, G. ; CRAVO, J. C. M. ; BERTOLINI, M. da S. ; ROCCO LAHR, F. A. Desempenho térmico de bezerreiros cobertos com telha de fibrocimento e forro ecológico de subprodutos agroindústrias associado a materiais isolantes. Revista Brasileira de Engenharia de Biossistemas, v.9, n.3. p.261-267, 2015. http://dx.doi.org/10.18011/bioeng2015v9n 3p261-267

BARBOSA FILHO, J. A. D.; SILVA, I. J. O.; SILVA, M. A. N.; SILVA, C. J. M. Mudanças e uso das tabelas de entalpia. Piracicaba, 2007. http://www.nupea.esalq.usp.br/tabelas-deentalpia/frangos-de-corte. 02 Fev. 2018.

CAMERINI, N. L.; NASCIMENTO, J. W. B. do; FOOK, M. V. L.; SOARES, E. A.; SILVA, F. A. S. Análise de variáveis ambientais em modelos reduzidos de instalações agropecuárias com forro de resíduo de EVA. Revista eletrônica de Materiais e Processos, v.4, n.2, p.40-47, 2009.

http://www.dema.ufcg.edu.br/revista/index .php/REMAP/article/viewFile/115/116

CARVALHO, H. G. Materiais de coberturas e suas associações a forros e materiais isolantes no ambiente térmico de protótipos abertos e fechados com vistas a produção de frangos de corte em clima wastes and the aviary without the panel.

This study was partially financed by the Coordenação de Aperfeiçoamento de Pessoal de Nível Superior - Brasil (CAPES) - Finance Code 001.

quente. Viçosa: Universidade Federal de Viçosa, 2013. 108p. Tese Doutorado.

CRAVO, JULIO CESAR MACHADO; SARTORI, DIOGO DE LUCCA; NAKANISHI, ERIKA YUKARI; FIORELLI, JULIANO; BALIEIRO, JULIO CESAR DE CARVALHO; SANTOS, WILSON NUNES DOS. Forro ecológico de resíduos agroindustriais para galpões avícolas. Ciência Rural (UFSM. Impresso). v. 44, p. 1466-1471, 2014.

CRAVO, J. C. M.; SARTORI, D. L. ; BALIEIRO, J. C. C. ; FIORELLI, J. . Compósito à base de resíduos agrícolas para aplicação como forro em aviários. Revista Brasileira de Engenharia de Biossistemas, v. 9, p. 358-367, 2015.

CRAVO, J. C. M.; SARTORI, D. L.; FIORELLI, J. Agro-industrial waste composites as components for rural buildings. In: Mohammad Jawaid; Paridah Md Tahir; Naheed Saba. (Org.). Lignocellulosic Fibre and Biomass-Based Composite Materials: Processing, Properties and Applications. 1ed.: ELSEVIER SCIENCE \& TECHNOLOGY, 2017. p. 13-25.

CASSUCE, D. C. Determinação das faixas de conforto térmico para frangos de corte de diferentes idades criados no Brasil. Viçosa: Universidade Federal de Viçosa, 2011. 103p. Tese Doutorado.

CASTRO JÚNIOR, S. L. de.; OLIVEIRA, D. C. G. de.; CANEPPELE, F.L.; FIORELLI, J. Thermal comfort in individual shelters for calves with nonconventional ceiling made of agro- 
industrial by-products. Brazilian Journal of Biosystems Engineering, v. 11 (4): 317325, 2017.

LOPES JÚNIOR, W. E.; FREITAS, G. C. de.; BARBIRATO, G. H. A.; FIORELLI, J. Análise de índices térmicos de protótipos de aviários com forro de fibra mineral. In: II Simpósio Internacional de Ambiência na Produção Animal Sustentável - SIAPAS / VI Simpósio Nacional de Construções Rurais e Ambiência-SIMCRA. 2019. P. 793-801.

LOURENÇONI, D. Análise do ambiente em galpões de poedeiras comerciais telados. Lavras: Universidade Federal de Lavras, 2013. 89p. Dissertação.

MACARI, M.; FURLAN, R. L.; Gonzales, E. Fisiologia aviária aplicada a frangos de corte. In: Furlan, R. L.; Macari, M. Termorregulação. Jaboticabal - SP: FUNEP/UNESP, 2002. p. 209-230.

MEDEIROS, C. M.; BÂETA, F. da C.; OLIVEIRA, R. F. M. de; TINÔCO, I. de. F. F.; ALBINO, L. F. T.; CECON, P. R. Índice térmico ambiental de produtividade para frangos de corte. Revista Brasileira de Engenharia Agrícola e Ambiental, v.9, n.4, p.660-665, 2005.

MENDONÇA, F.; DANNI-OLIVEIRA, I. M. Climatologia: noções básicas e climas do Brasil. São Paulo, 2011. 206 p.

NAVARINI, F.C. Níveis de Proteína Bruta e Balanço Eletrolítico para Frangos de Corte. Marechal Cândido Rondon: Universidade Estadual do Oeste do Paraná, 2009. 73p. Dissertação.
ORGANIZAÇÃO PARA COOPERAÇÃO E DESENVOLVIMENTO ECONÔMICO (OCDE)/ORGANIZAÇÃO DAS NAÇÕES UNIDAS PARA AGRICULTURA E ALIMENTAÇÃO (FAO) (2017), “OCDEFAO Perspectivas Agrícolas", Estatísticas da OCDE sobre agricultura (base de dados), http://www.fao.org/3/a-i7465s.pdf

RODRIGUES, V. C.; SILVA, I. J. O.; VIEIRA, F. M. C.; NASCIMENTO, S. T. A correct enthalpy relationship as thermal comfort index for livestock. International Journal of Biometeorology, v.55, p.455-459, 2011.

SCHIASSI, L.; JÚNIOR, T. Y.; REIS, G. M.; ABREU, L. H. P.; CAMPOS, A. T.; CASTRO, J. de O. Modelagem Fuzzy aplicada na avaliação do desempenho de frangos de corte. Revista Brasileira de Engenharia Agrícola e Ambiental, v.19, n.2, p.140-146, 2015. http://dx.doi.org/10.1590/18071929/agriambi.v19n2p140-146.

SIMOES, M. G.; SHAW, I. S. Controle e modelagem fuzzy. São Paulo: Blucher: FAPESP, 2007. 198 p.

TINÔCO, I. F. F. Avicultura industrial: novos conceitos de materiais, concepções e técnicas construtivas disponíveis para galpões avícolas brasileiros. Revista Brasileira de Ciência Avícola, v.3, n.1, p.126, 2001.

http://www.scielo.br/scielo.php?pid=S151 $6635 X 2001000100001 \&$ script=sci_abstrac t\&tlng=pt. 23 Fev. 2018. doi: 10.1590/S1516-635X2001000100001. 